\title{
Article \\ High Incidence of Cataracts in the Follow-Up of Patients Undergoing Percutaneous Coronary Intervention for Chronic Coronary Total Occlusion
}

\author{
Ricardo Rivera-López ${ }^{1,2}{ }^{\mathbb{D}}$, Celia García-López ${ }^{3, * \mathbb{D}}$, José M. Sánchez-Moreno ${ }^{1} \mathbb{D}$, Rafael A. Rivera-López ${ }^{4}$, \\ Julio Almansa-López ${ }^{5}$ (D), Ricardo Rivera-Fernández ${ }^{6}$, Eduardo Molina-Navarro ${ }^{1}$, Miriam Jiménez-Fernández ${ }^{1}$, \\ Santiago Ortiz-Pérez ${ }^{2,3,4}$ (i) and José A. Ramírez-Hernández ${ }^{1,2,7}$
}

1 Cardiology Department, Virgen de las Nieves University Hospital, 18014 Granada, Spain; rfriveralopez@gmail.com (R.R.-L.); josemanuel34sm@gmail.com (J.M.S.-M.); edumolina64@hotmail.com (E.M.-N.); mirijf84@hotmail.com (M.J.-F.); ramirezj@ugr.es (J.A.R.-H.)

2 Biosanitary Research Institute ibs.GRANADA, 18012 Granada, Spain; drsantiagoortiz@gmail.com

3 Department of Ophtalmology, University Hospital Virgen de las Nieves, Av. de las Fuerzas Armadas, 2, 18014 Granada, Spain

4 University of Granada (UGR), 18016 Granada, Spain; rafaelriveralopez@correo.ugr.es

5 Radiophysics Department, Virgen de las Nieves University Hospital, 18014 Granada, Spain; jalmansa.lopez@gmail.com

check for updates

Citation: Rivera-López, R.; García-López, C.; Sánchez-Moreno, J.M.; Rivera-López, R.A.;

Almansa-López, J.; Rivera-Fernández, R.; Molina-Navarro, E.; Jiménez-Fernández, M.; Ortiz-Pérez, S.; Ramírez-Hernández, J.A. High Incidence of Cataracts in the Follow-Up of Patients Undergoing Percutaneous Coronary Intervention for Chronic Coronary Total Occlusion. J. Clin. Med. 2021, 10, 5002. https:// doi.org/10.3390/jcm10215002

Academic Editor: Olivier Morel

Received: 16 September 2021

Accepted: 26 October 2021

Published: 27 October 2021

Publisher's Note: MDPI stays neutral with regard to jurisdictional claims in published maps and institutional affiliations.

Copyright: (c) 2021 by the authors. Licensee MDPI, Basel, Switzerland. This article is an open access article distributed under the terms and conditions of the Creative Commons Attribution (CC BY) license (https:/ / creativecommons.org/licenses/by/ $4.0 /)$.
6 Intensive Care Department, University Hospital of Jaén, 23007 Jaén, Spain; rriverafernandez@gmail.com

7 Medicine Department, University of Granada (UGR), 18016 Granada, Spain

* Correspondence: celg189@gmail.com; Tel.: +34-958020009

Abstract: Development of cataracts is a well-known adverse effect of ionizing radiation, but little information is available on their incidence in patients after other medical procedures, such as cardiac catheterizations. The study objective was to determine the incidence of cataracts in a cohort of patients undergoing percutaneous coronary intervention (PCI) for chronic coronary total occlusion (CTO) and its association with radiation dose. The study analyzed the incidence of cataracts during the follow-up of 126 patients who underwent chronic total coronary PCI, using Cox regression to identify predictive factors of cataract development. The study included 126 patients, $86.9 \%$ male, with a mean age of 60.5 years (range, 55.0-68.0 years). Twenty-three $(18.2 \% n=23)$ developed cataracts during a mean follow-up of 49.5 months (range 37.3-64.5 months). A higher incidence was observed in patients who received more than 5 Gy $(29.0 \%$ vs. $14.7 \%$, Hazard ratio $(\mathrm{HR}=2.84$ [1.19-6.77]). Multivariate analysis revealed a relationship between cataract development during the follow-up and a receipt of radiation dose $>5 \mathrm{~Gy}(\mathrm{HR}=2.60,95 \%$ confidence interval [CI 1.03-6.61]; $p=0.03)$, presence or history of predisposing eye disease ( $\mathrm{HR}=4.42, \mathrm{CI}: 1.57-12.40)$, diabetes ( $\mathrm{HR}=3.33$ [1.22-9.24]), and older age, as in $>57$ (HR, 6.40 [1.81-22.61]). An elevated incidence of cataracts was observed in patients after PCI for CTO. The onset of cataracts is related to the radiation dose during catheterization, which is a potentially avoidable effect of which operators should be aware.

Keywords: cataracts; ionizing radiation; chronic coronary total occlusion; percutaneous coronary intervention

\section{Introduction}

Percutaneous coronary intervention (PCI) is a well-established treatment of acute and chronic ischemic heart disease. Increasing numbers of patients undergo this intervention [1], and technological improvements have increased success rates [2].

There has been a corresponding increase in the performance of PCI for chronic coronary total occlusion (CTO) [2] after the demonstration of its usefulness in selected patients [3-5]. This is a technically complex procedure that requires specific material, specially trained staff, a large amount of contrast, and long fluoroscopy times with a consequent increase in the radiation dose [6-9]. 
Adverse effects of ionizing radiation are well documented, including stochastic effects (e.g., the development of certain types of cancer) and deterministic effects (e.g., radioinduced cataracts, erythema, infertility, etc.) [10].

The development of cataracts due to ionizing radiation was first described in survivors of the atom bombs exploded over Hiroshima and Nagasaki [11]. There are increasing concerns about exposure to radiation at work and during medical examinations and procedures and about its possible mid- to long-term effects.

Various studies have shown that radiation doses previously considered safe can be responsible for the development of cataracts in humans [11-15]. Based on this evidence, the limit for occupational exposure to an equivalent dose to the crystalline lens has been reduced to $20 \mathrm{mSv}$ /year [16].

Numerous authors have examined the frequency of cataract development in radiologists and interventional cardiologists, among other clinicians [13-17], but there have been few studies of patients undergoing procedures that involve ionizing radiation [18-20]. A search of the literature revealed no investigations that specifically studied patients after PCI. In this regard, CTO uses particularly high radiation doses [6-9], and patients may be especially susceptible to developing cataracts after this procedure.

The objectives of this study were to determine the incidence of cataracts after treatment by PCI for CTO, and to explore any relationship between radiation dose during catheterization and subsequent cataract development.

\section{Materials and Methods}

\subsection{Study Population}

This observational, retrospective cohort study included consecutive patients undergoing PCI for CTO at our center between 2013 and 2017. Exclusion criteria were: previous cataract diagnosis or follow-up $<12$ months (due to loss to follow-up or death), The study protocol was approved by the ethics committee of our center.

\subsection{Study Variables}

Data were gathered on: demographic characteristics; cardiovascular risk factors; radiation dose during PCI for CTO, reported as kerma-area product $\left(\mathrm{P}_{\mathrm{KA}}\left[\mathrm{mGy} \cdot \mathrm{cm}^{2}\right]\right)$ and air kerma at the patient entrance reference point $\left(\mathrm{K}_{\mathrm{a}, \mathrm{r}}[\mathrm{mGy}]\right)$; chronic corticoid consumption, i.e., uninterrupted intake for $\geq 3$ months; cataract-related medical history, including uveitis, laser therapy in anterior segment or retina, receipt of intravitreal medication, eye surgery, eye disease, retinal detachment, diabetic retinopathy, and myopic chorioretinopathy.

\subsection{Cataract Follow-Up and Identification}

Patients underwent clinical follow up, recording referrals to an ophthalmologist for reduced visual acuity and defining the presence of cataracts by a reduction $>0.5$ in visual acuity and the biomicroscopic observation of crystalline lens opacification. Follow-up data were gathered by a cardiologist (RRL) and an ophthalmologist (CGL) from hospital clinical records, health center records, and telephone interviews with patients (Figure 1).

\subsection{Dose Calculation}

All catheterizations were performed in hemodynamic rooms with a Philips Allura Xper FD10 system (7.2.16, Philps Iberica, MARIA DE PORTUGAL, 1, Madrid, Spain). Dosimetry information for each procedure was collected from the data in the radiation dose structured reports (RDSR) of the equipment and was stored and processed using the OpenREM platform (https:/ / openrem.org, last access 16 September 2021). 

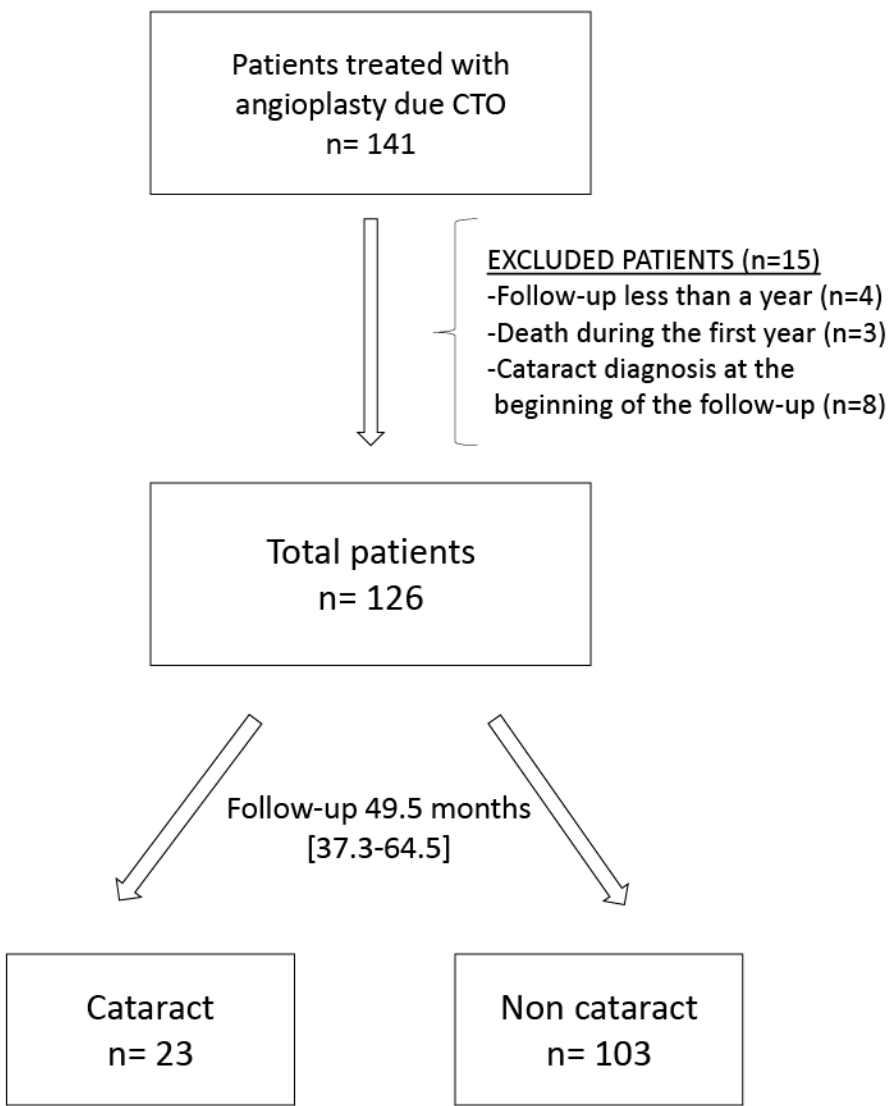

\section{Non cataract}

$n=103$

Figure 1. Flow chart of patient selection.

\subsection{Statistical Analysis}

Quantitative variables were expressed as medians (25-75 percentiles) and qualitative variables as absolute and relative frequencies. The Long-Rank test was used to compare cataract onset times over the follow-up, calculating the HR. For comparative analyses, quantitative variables were transformed into qualitative variables, grouping values by tertiles or quartiles. The fourth quartile of radiation dose was compared with the other three quartiles and the upper tertiles of age were grouped together to facilitate presentation of the data and to obtain a more homogeneous distribution.

Cox regression multivariate analysis was performed with cataract onset as the dependent variable, entering independent variables obtaining $p<0.20$ in bivariate analysis and removing variables with $p>0.05$.

\section{Results}

Figure 1 depicts the flow of patients through the study. The final study sample comprised 126 patients, $86.9 \%$ of whom males, with an age of 60.5 years (range, 55.0-68.0 years) and a median follow-up period of 49.5 [37.3-64.5] months.

\subsection{Bivariate Analysis}

The incidence of cataracts was $18.2 \%(n=23)$. Patients developing cataracts were older, more often diabetic, more frequently had a predisposing eye disease, and received a higher radiation dose, with a marked difference between patients in the fourth quartile versus the other three quartiles (Table 1). 
Table 1. Baseline characteristics of the study population and their relationship with cataract development.

\begin{tabular}{|c|c|c|c|}
\hline Variable & Total $(n=126)$ & Cataracts $(n=23)$ & $p$ \\
\hline Age & & & 0.11 \\
\hline$\leq 56$ years & 42 & $3(7.1 \%)$ & \\
\hline $57-65$ years & 42 & $10(23.8 \%)$ & \\
\hline$>65$ years & 42 & $10(23.8 \%)$ & \\
\hline Age $>56$ years & 84 & $20(23.8 \%)$ & 0.03 \\
\hline Sex female & 14 & $3(21.4 \%)$ & 0.60 \\
\hline Hypertension & 97 & $17(17.5 \%)$ & 0.58 \\
\hline Diabetes & 50 & $15(30 \%)$ & 0.01 \\
\hline Dyslipidemia & 78 & $13(16.7 \%)$ & 0.52 \\
\hline Chronic renal failure & 8 & $1(12.5 \%)$ & 0.76 \\
\hline CABG & 3 & $1(33.3 \%)$ & 0.37 \\
\hline Smoking habit & 51 & $5(9.8 \%)$ & 0.08 \\
\hline Corticoid consumption & 10 & $1(10 \%)$ & 0.52 \\
\hline Previous eye disease * & 15 & $7(46.6 \%)$ & 0.01 \\
\hline Fluoroscopy time $>40 \mathrm{~min}$ & 67 & $14(20.8 \%)$ & 0.47 \\
\hline Radiation dose & & & 0.11 \\
\hline$\leq 1.9 \mathrm{~Gy}$ & 31 & $6(19.3 \%)$ & \\
\hline $1.95-2.60 \mathrm{~Gy}$ & 32 & $5(15.6 \%)$ & \\
\hline $2.7-4.9 \mathrm{~Gy}$ & 32 & $3(9.3 \%)$ & \\
\hline$\geq 5$ Gy & 31 & $9(29.0 \%)$ & \\
\hline Dose $\geq 5$ Gy & 31 & $9(29.0 \%)$ & 0.01 \\
\hline
\end{tabular}

CABG: Coronary artery bypass grafting; ${ }^{*}$, e.g., uveitis, laser therapy in anterior segment or retina, intravitreal medication, or disease that reduces visual acuity such as retinal detachment, diabetic retinopathy, myopic chorioretinopathy, or eye surgery.

\subsection{Multivariate Analysis}

In the multivariate analysis (Table 2), cataract development was associated with older age, diabetes, predisposing eye disease, and the receipt of a radiation dose $>5$ Gy during catheterization. Smoking habit exited the model.

Table 2. Multivariate analysis, dependent variable "cataract onset".

\begin{tabular}{ccccc}
\hline & \multicolumn{2}{c}{ Univariable Model } & \multicolumn{2}{c}{ Multivariable Model } \\
\cline { 2 - 5 } & HR (95\% CI) & $p$ Value & HR (95\% CI) & $p$ Value \\
\hline Dose > 5 Gy & $2.84[1.19-6.77]$ & 0.018 & $2.60[1.03-6.61]$ & 0.044 \\
\hline Previous eye disease $^{*}$ & $5.63[2.26-14.04]$ & 0.014 & $4.42[1.57-12.40]$ & 0.005 \\
\hline Age > 56 years & $3.64[1.08-12.29]$ & 0.037 & $6.40[1.81-22.61]$ & 0.004 \\
\hline Diabetes & $4.57[1.81-11.56]$ & 0.010 & $3.33[1.22-9.24]$ & 0.020 \\
\hline Smoking ** & $0.42[0.16-1.12]$ & 0.084 & $0.86[0.29-2.59]$ & 0.791 \\
\hline
\end{tabular}

* as in Table 1. ** Variable that exited the model.

\section{Discussion}

In this study, around one-fifth of patients exposed to radiation during PCI developed cataracts within four years after the intervention. The risk of cataract onset was related to the radiation dose and was two-fold higher in patients in the upper dose quartile versus the other three quartiles. 
CTO treatment is a reasonable option for selected patients and is associated with a high success rate $[2,4,5]$. Although complications associated with the radiation or contrast dose have previously been reported, the long-term effects of the radiation dose received by patients have been less well studied. These findings on the incidence of cataracts highlight the need to minimize the radiation dose selected for the procedure, inform the patients about the risks involved, and schedule regular ophthalmological examinations during the follow-up.

Data have been published on the incidence of cataracts among radiology and interventional cardiology personnel [12-15]. However, fewer studies have been performed on patients, focusing on those receiving direct cranial radiation and showing a high incidence of cataracts [17-19]. The effect of disperse radiation on the crystalline lens of patients is examined in the present study, with noteworthy results.

The present patient population had a high prevalence of risk factors for both ischemic heart disease and cataracts [21]. This suggests a multifactorial origin of cataracts, although the radiation dose has a highly significant effect when other variables are equal.

The radiation dose used in our series is elevated, as reported in other studies of CTOs [6-9]. Operators in these frequently long and complex procedures should be aware of the risks of radiation and must consider strategies to minimize the dose (e.g., lowdose mode, pulse or image rate reduction, use of collimation, etc.), implementing dosemonitoring programs and the new image-improvement technologies included in the most modern equipment [22-25].

Data on the prevalence and incidence of cataracts in our general population would be of interest but are difficult to gather, explaining the scant epidemiological publications on this issue [26]. The WHO estimated that 94 million people worldwide had visual disability due to cataracts in 2020 [27]. Various studies of Latino and Asian populations reported an increase in the prevalence of this disease with higher age, from $3.9 \%$ in the 55-to-64-year age group to around $92.6 \%$ over the age of 80 years [28-30]. However, most of these investigations were based on an active search for the presence of cataracts in the population, whereas our study only included patients seeking medical care for the loss of vision due to cataracts.

Ischemic heart disease and cataracts share type II DM, obesity and tobacco use as risk factors [28], and an association has been reported between the development of these two diseases [31]. This should be taken into account when interpreting our results, although the elevated incidence of cataracts in our population is striking, especially given the age of patients at its onset.

The prevention and early diagnosis of cataracts can be improved by determining risk factors in the general population and establishing whether therapeutic procedures using ionizing radiation contribute to increase its incidence and lower the age at onset. If this proves to be the case, preventive strategies could be adopted to protect the crystalline lens of patients from the radiation.

This study was limited to patients undergoing CTO treatment; however, account should be taken of the risk of cataracts in other procedures that involve similar radiation doses. Further studies with larger samples are warranted to verify the present findings.

\section{Limitations}

Radiation doses were only studied during the CTO catheterization procedure, which is less precise than a full dosimetry history of the patient. However, this nondifferential classification bias was equally present in both groups. In addition, the Product kerma-area $\left(\mathrm{P}_{\mathrm{KA}}\left[\mathrm{mGy} \cdot \mathrm{cm}^{2}\right)\right.$ and air kerma at the patient entrance reference point $\left(\mathrm{K}_{\mathrm{a}, \mathrm{r}}[\mathrm{mGy}]\right)$ were considered for the correlation between dose and cataract onset, and these magnitudes are not directly related to the dose in the crystalline lens, whose estimation is highly challenging. However, they are directly available from the equipment and easily measured for validation, and this is also a nondifferential bias. These magnitudes are also used to characterize interventional procedures and facilitate comparisons with other reports 
on CTO procedures. In addition, there was no untreated control group with similar characteristics for comparison of the incidence of cataracts over the follow-up period, which is an important limitation. Nevertheless, our observation of an incidence of $18 \%$ in a relatively young cohort is a noteworthy finding that warrants further research.

Finally, the sample size was relatively small, and the catheterization exposed all patients to elevated radiation doses. Hence, studies in larger patient samples with a wider range of radiation doses are required to verify these results and allow their extrapolation to different situations and settings.

\section{Conclusions}

The incidence of cataracts is elevated after PCI for CTO and is related to the radiation dose received during catheterization. Operators should be aware of this adverse effect and adopt measures to reduce the exposure of patients to radiation during this and similar procedures. Further studies in larger samples are needed to verify these results and explore measures for minimizing the radiation dose.

Author Contributions: Conceptualization, R.R.-L., J.A.-L., J.M.S.-M. and C.G.-L.; methodology, R.A.R.-L., R.R.-L., C.G.-L., J.A.-L. and J.M.S.-M.; software, J.M.S.-M., J.A.-L., validation, R.R.-L., C.G.L., J.A.-L. and J.M.S.-M.; formal analysis, R.R.-L.; investigation, R.R.-L., J.A.-L., C.G.-L., J.M.S.-M., R.R.-F., E.M.-N., M.J.-F., R.A.R.-L.; resources; writing-original draft preparation, R.R.-L., J.A.-L. and C.G.-L.; writing-review and editing S.O.-P., J.A.R.-H.; visualization. R.R.-L. and C.G.-L.; supervision, S.O.-P., J.A.R.-H.; project administration, S.O.-P., J.A.R.-H. All authors have read and agreed to the published version of the manuscript.

Funding: This research was not funded.

Institutional Review Board Statement: The study was conducted according to the guidelines of the Declaration of Helsinki and Institutional Review Board approval was obtained.

Informed Consent Statement: Written informed consent was not required for this study.

Data Availability Statement: The data analyzed in this study are available from the corresponding author upon reasonable request.

Conflicts of Interest: The authors declare no conflict of interests.

\section{References}

1. Serrador Frutos, A.M.; Jiménez-Quevedo, P.; Pérez de Prado, A.; Pan Álvarez-Ossorio, M. Spanish Cardiac Catheterization and Coronary Intervention Registry. 26th Official Report of the Spanish Society of Cardiology Working Group on Cardiac Catheterization and Interventional Cardiology (1990-2016). Rev. Española Cardiol. Engl. Ed. 2017, 70, 1110-1120. [CrossRef]

2. Neumann, F.J.; Sousa-Uva, M.; Ahlsson, A.; Alfonso, F.; Banning, A.P.; Benedetto, U.; Byrne, R.A.; Collet, J.P.; Falk, V.; Head, S.J.; et al. 2018 ESC/EACTS Guidelines on myocardial revascularization. Eur. Heart J. 2019, 40, 87-165. [CrossRef]

3. Werner, G.S.; Martin-Yuste, V.; Hildick-Smith, D.; Boudou, N.; Sianos, G.; Gelev, V.; Rumoroso, J.R.; Erglis, A.; Christiansen, E.H.; Escaned, J.; et al. A randomized multicentre trial to compare revascularization with optimal medical therapy for the treatment of chronic total coronary occlusions. Eur. Heart J. 2018, 39, 2484-2493. [CrossRef]

4. Mehran, R.; Claessen, B.E.; Godino, C.; Dangas, G.D.; Obunai, K.; Kanwal, S.; Carlino, M.; Henriques, J.P.S.; Di Mario, C.; Kim, Y.H.; et al. Long-term outcome of percutaneous coronary intervention for chronic total occlusions. JACC Cardiovasc. Interv. 2011, 4, 952-961. [CrossRef]

5. Joyal, D.; Afilalo, J.; Rinfret, S. Effectiveness of recanalization of chronic total occlusions: A systematic review and meta-analysis. Am. Heart J. 2010, 160, 179-187. [CrossRef]

6. Xenogiannis, I.; Karmpaliotis, D.; Alaswad, K.; Jaffer, F.A.; Yeh, R.W.; Patel, M.; Mahmud, E.; Choi, J.W.; Burke, M.N.; Doing, A.H.; et al. Impact of concomitant treatment of non-chronic total occlusion lesions at the time of chronic total occlusion intervention. Int. J. Cardiol. 2020, 299, 75-80. [CrossRef] [PubMed]

7. Tajti, P.; Alaswad, K.; Karmpaliotis, D.; Jaffer, F.A.; Yeh, R.W.; Patel, M.; Mahmud, E.; Choi, J.W.; Burke, M.N.; Doing, A.H.; et al. In-hospital Outcomes of Attempting More than One Chronic Total Coronary Occlusion Through Percutaneous Intervention during the Same Procedure. Am. J. Cardiol. 2018, 122, 381-387. [CrossRef] [PubMed]

8. Wilson, W.M.; Walsh, S.; Hanratty, C.; Strange, J.; Hill, J.; Sapontis, J.; Spratt, J.C. A novel approach to the management of occlusive in-stent restenosis (ISR). EuroIntervention 2014, 9, 1285-1293. [CrossRef] [PubMed]

9. Jen, T.H.; Tamai, H.; Kyo, E.; Tsuji, T.; Watanabe, S. Traditional antegrade approach versus combined antegrade and retrograde approach in the percutaneous treatment of coronary chronic total occlusions. Catheter. Cardiovasc. Interv. 2009, 74, 555-563. 
10. Clement, C.H.; Stewart, F.A.; Akleyev, A.V.; Hauer-Jensen, M.; Hendry, J.H.; Kleiman, N.J.; Macvittie, T.J.; Aleman, B.M.; Edgar, A.B.; Mabuchi, K.; et al. ICRP publication 118: ICRP Statement on Tissue Reactions and Early and Late Effects of Radiation in Normal Tissues and Organs Ã $₫ \hat{a}, \neg a ̂ €$ Threshold Doses for Tissue Reactions in a Radiation Protection Context. Ann. ICRP 2012, 41, 1-322. [CrossRef] [PubMed]

11. Neriishi, K.; Nakashima, E.; Minamoto, A.; Fujiwara, S.; Akahoshi, M.; Mishima, H.K.; Kitaoka, T.; Shore, R.E. Postoperative cataract cases among atomic bomb survivors: Radiation dose response and threshold. Radiat. Res. 2007, 168, 404-408. [CrossRef] [PubMed]

12. Kleiman, N.J. Radiation cataract. Ann ICRP 2012, 41, 80-97. [CrossRef] [PubMed]

13. Vano, E.; Kleiman, N.J.; Duran, A.; Rehani, M.M.; Echeverri, D.; Cabrera, M. Radiation cataract risk in interventional cardiology personnel. Radiat. Res. 2010, 174, 490-495. [CrossRef]

14. Ciraj-Bjelac, O.; Rehani, M.M.; Sim, K.H.; Liew, H.B.; Vano, E.; Kleiman, N.J. Risk for radiation-induced cataract for staff in interventional cardiology: Is there reason for concern? Catheter. Cardiovasc. Interv. 2010, 76, 826-834. [CrossRef]

15. Klein, B.E.K.; Klein, R.; Linton, K.L.P.; Franke, T. Diagnostic x-ray exposure and lens opacities: The Beaver Dam Eye Study. Am. J. Public Health 1993, 83, 588-590. [CrossRef] [PubMed]

16. Unión Europea. DIRECTIVA 2013/59/EURATOM DEL CONSEJO de 5 de Diciembre de 2013, por la que se Esta-Blecen Normas de Seguridad Basicas Para la Protección Contra los Peligros Derivados de la Exposición a Radia-Ciones Ionizantes. D of la Unión Eur [Internet]. 2014. L13/1-73. Available online: http:/ /www.boe.es/doue/2014/013/L00001-00073.pdf (accessed on 26 October 2021).

17. Miller, D.L.; Vañó, E.; Bartal, G.; Balter, S.; Dixon, R.; Padovani, R.; Schueler, B.; Cardella, J.F.; De Baère, T. Occupational radiation protection in interventional radiology: A joint guideline of the cardiovascular and interventional radiology society of Europe and the society of interventional radiology. Cardiovasc. Intervent. Radiol. 2010, 33, 230-239. [CrossRef]

18. Hourihan, F.; Mitchell, P.; Cumming, R.G. Possible associations between computed tomography scan and cataract: The blue mountains eye study. Am. J. Public Health 1999, 89, 1864-1866. [CrossRef] [PubMed]

19. Yuan, M.K.; Tsai, D.C.; Chang, S.C.; Yuan, M.C.; Chang, S.J.; Chen, H.W.; Leu, H.B. The risk of cataract associated with repeated head and neck CT studies: A nationwide population-based study. Am. J. Roentgenol. 2013, 201, 626-630. [CrossRef] [PubMed]

20. Cheng, K.L.; Huang, J.Y.; Su, C.L.; Tung, K.C.; Chiou, J.Y. Cataract risk of neuro-interventional procedures: A nationwide population-based matched-cohort study. Clin. Radiol. 2018, 73, 836.e17-836.e22. [CrossRef]

21. Nam, S.W.; Lim, D.H.; Cho, K.Y.; Kim, H.S.; Kim, K.; Chung, T.Y. Risk factors of presenile nuclear cataract in health screening study. BMC Ophthalmol. 2018, 18, 1-9. [CrossRef]

22. International Atomic Energy Agency. Patient Dose Optimization in Fluoroscopically Guided Interventional Procedures; IAEA: Vienna, Austria, 2010; ISBN 9789201005106.

23. Tsapaki, V. Radiation dose optimization in diagnostic and interventional radiology: Current issues and future perspectives. Phys. Med. 2020, 79, 16-21. [CrossRef] [PubMed]

24. Ainsbury, E.A.; Bouffler, S.D.; Dörr, W.; Graw, J.; Muirhead, C.R.; Edwards, A.A.; Cooper, J. Radiation cataractogenesis: A review of recent studies. Radiat Res. 2009, 172, 1-9. [CrossRef] [PubMed]

25. Shore, R.E.; Neriishi, K.; Nakashima, E. Epidemiological studies of cataract risk at low to moderate radiation doses: (Not) seeing is believing. Radiat. Res. 2010, 174, 889-894. [CrossRef] [PubMed]

26. Begiristain, J.M.; Ibarlucea, J. Incidencia y prevalencia de cataratas. In Cirugía del Cristalino; Sociedad Española de Oftalmología: Mardid, Spain, 2008; Volume 1, pp. 165-172.

27. WHO. Visual Impairment and Blindness. 2014. Available online: http://www.who.int/mediacentre/factsheets/fs282/en/ (accessed on 17 October 2021).

28. Chua, J.; Koh, J.Y.; Tan, A.G.; Zhao, W.; Lamoureux, E.; Mitchell, P.; Wang, J.J.; Wong, T.Y.; Cheng, C.Y. Ancestry, socioeconomic status, andage-related cataract in Asians: The Singapore Epidemiology of EyeDiseases Study. Ophthalmology 2015, 122, 2169-2178. [CrossRef]

29. Varma, R.; Torres, M. Prevalence of lens opacities in Latinos:the Los Angeles Latino Eye Study. Ophthalmology 2004, 111, 1449-1456. [CrossRef]

30. Liu, Y.-C.; Wilkins, M.; Kim, T.; Malyugin, B.; Mehta, J.S. Cataracts. Lancet 2017, 390, 600-612. [CrossRef]

31. Hu, F.B.; Hankinson, S.E.; Stampfer, M.J.; Manson, J.E.; Colditz, G.A.; Speizer, F.E.; Hennekens, C.H.; Willett, W.C. Prospective Study of Cataract Extraction and Risk of Coronary Heart Disease in Women. Am. J. Epidemiol. 2001, 153, 875-881. [CrossRef] [PubMed] 